\title{
Fictions of the Modern Architectural Narrative: An Epistemological Construct of Oppositions and Discontinuities
}

\author{
Modern Mimarlık Anlatisının Kurguları: \\ Karşıtlık ve Süreksizliklerin Bilgi Kuramsal Yapısı
}

\section{Selim ÖKEM}

\section{ABSTRACT}

The research presented here questions the possibility of drawing an outline of the structure of modern architectural knowledge, and how the concepts of 'discontinuity' and 'opposition' could be utilized in attaining an epistemological reading of such an outline. A contextual analysis of texts and visual material provides compatible data on how oppositions could form the basis of a late modern architectural episteme. The method of the research includes classification of these texts and visual content and an interpretive study of the classified visual material to determine the major oppositions in modern architectural discourse. Along with this nonreactive contextual research method, a close-ended survey was conducted among a sample of architectural students to evaluate the epistemological value of these oppositions. Findings of this research showed that, in part, the oppositions (being a derivative of the notion of discontinuity) were what made modern architectural knowledge impartible (teachable), legible (readable) and permeable (absorbable, expressible).

\section{Introduction}

One of the reasons architectural episteme can be conceived, conveyed and transformed is because it is an amalgam of different narratives. Every narrative is based on a fiction that has a beginning and an end. The narratives construct a transitional story in between the conditions portrayed at the beginning and at the

\section{ÖZET}

Bu metin kapsamında sunulan araştırma, modern mimarlık bilgisinin yapısına dair şemanın nasıl şekillendiğini ve 'karşıtlık' ve 'süreksizlik' kavramları üzerinden modern mimarlık söyleminin bilgi kuramsal bir okumasının nasıl yapılabileceğini sorgulamaktadır. Metin ve görsel materyalin bağlamsal çözümlemesi, geç modern mimarlık bilgisinin temelinin karşıtlıklar üzerine nasıl şekillendiği konusunda gözlemlenebilir verinin toplanması yönünde kullanılmıştır. Araştırmada kullanılan yöntem, metinlerin ve görsel içeriğin sınıflandırılarak, modern mimarlık söylemindeki temel karşıtıkların belirlenmesinde yoruma dayalı bir çözümlemenin yapılmasını içermektedir. Bahsi edilen bu bağlamsal araştırma yöntemi bir geri beslemeden yoksun olduğundan, söz konusu karşıtlıkların bilgi kuramsal değerinin belirlenmesi amacıyla, lisans ve lisansüstü düzeydeki mimarlık öğrencilerinden oluşan bir örneklem gurubuna kapalı uçlu bir anket yöneltilmiştir. Araştırmanın bulguları (metinde süreksizliklerin bir türevi olarak ortaya çıktığı vurgulanan) karşıtıkların, modern mimarlık bilgisinin öğrenilebilirliği, okunabilirliği ve ifade edilebilirliği konusundaki yeri hakkında bilgi sağlamıştır.

end of a given fiction. Thus, the beginning and the end of each narrative is in an oppositional relation to each other.

The modern architectural narrative is constituted of a wide range of fictions related to aesthetics, ethics, meaning, presence, form, building program, typologies etc... The reason why they are named as 'fic-

Yıldız Technical University, Department of Architecture, Istanbul, Turkey. Yıldız Teknik Üniversitesi, Mimarlık Bölümü, Istanbul. 


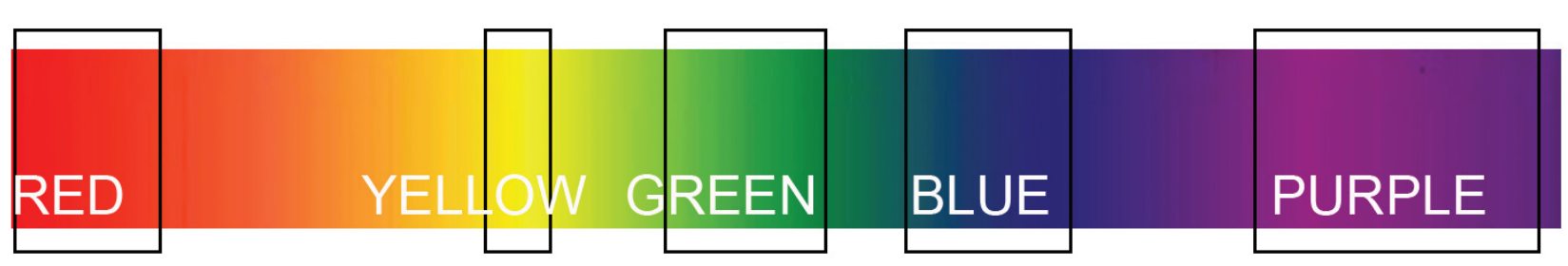

Figure 1. The continuous character of natural phenomenon of visible spectrum light, and the discontinuous cognitive construct of colors.

tions' within the scope of this paper is that, although the oppositions that lie beneath them have changed, the oppositional character of the narrative construct that they have set up through different historical eras has remained unchanged. In other words, the value of truth concerning the modern architectural knowledge is fictional more than being universal, natural or timeless.

The concepts of discontinuity and oppositions can portray a critical review on how the modern architectural knowledge has been constructed. Such a critical review can be utilized in the making of future theorizations of architectural education and in the making of reinterpretations of formal architectural language.

Reading the modern architectural episteme with the notions of discontinuity and oppositions is one in many ways of making an interpretive research in architectural theory. A contextual analysis of modern architectural episteme using linguistic terms discontinuity and oppositions as the main discursive method could explain how those notions play somewhat a basic role in the construction of the modern architectural knowledge.

\section{Defining the Terms: Discontinuity and Opposition}

How do we make sense of the world? How do we interpret things that surround us? To structuralists of 20th century, like Saussurre, Barthes, Strauss and alike, we do this by means of creating discontinuities within the continuous character of nature. Those who set the foundations of structuralism debate on how lingual information is organized. To them, all natural phenomena exhibit a continuous character. The information is possible only when the natural phenomenon is divided into discontinuous cognitive parts. Barthes iterates this issue by the continuity of the visible spectrum of light where no distinctive differentiation between the color hues is possible. It is the human mind that construct such a discontinuity and call it colors like, red, yellow, green, blue, etc., thus being able to use this informational pattern in a communicational exchange. [1] In other words colors are the cognitive construct of discontinuities humans create with respect to the continuous physical reality of visible spectrum of light.

E. Leach calls this pattern, categorization. ${ }^{[2]}$ To him, construction of categories is crucial to meaningful thought. Different cultures form transitional relations between constructed categories, i.e., the culinary habits, marital ceremonies and spatial behavioral patterns of man are in transition with each other. Leach states that marriage between people from the same household is prohibited and regarded as incest. Likewise pet animals that live in the household are not eaten. Marriage of people within the village, neighborhood or tribe is viable. In the same sense, livestock raised within the boundaries of the village, neighborhood or tribe is good for eating. On the other hand, animals from the wild can be eaten on the occasion when the marriage of people from different tribes or villages is at stake. Marriage from outside the tribe is rare and happens for a distinctive reason: say for territorial expansion or for merger. The feast that will be served in the wedding ceremony will be one from the wild. The constructed categories of what to eat, who to marry and where to live are in transition with each other as stated in Figure 2.

Similarly, Strauss in his culinary triangle, notes the different categories of cooking (boiling, roasting, smoking) and its transitional relation to whom the cooked material is served. The boiled meat holds water and is not completely natural which is mostly associated with women and served to closed groups, such as families. Roasting on the other hand involves exposing meat

\begin{tabular}{|c|c|c|}
\hline Spatial perception & Culinary & Marital ceremony \\
\hline Household & Pets & Incest \\
\hline Neighborhood & Livestock & Common marriage \\
\hline The Wild (Inter-Tribal) & Feast & Merger or territorial expanse \\
\hline \multicolumn{3}{|l|}{ Legend: } \\
\hline Prohibited & Viable & Conditional \\
\hline
\end{tabular}

Figure 2. Leach's transitional relations between constructed categories: culinary and marital ceremony. 


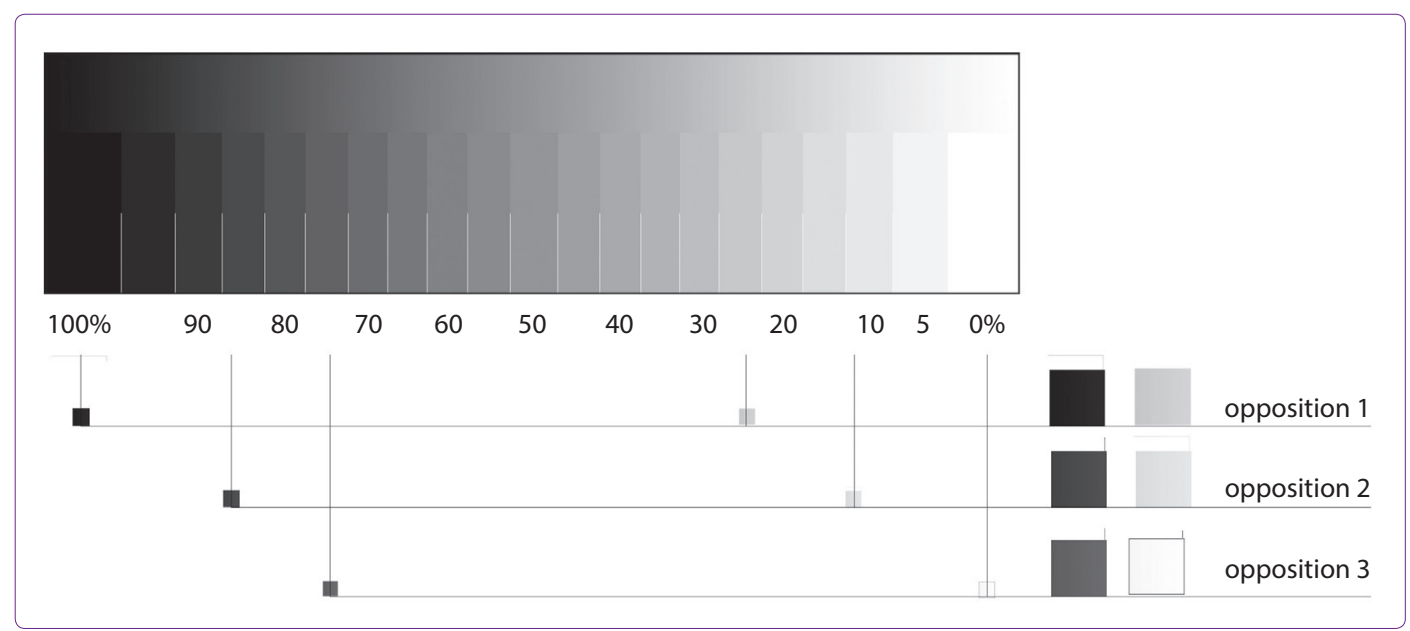

Figure 3. The opposition and its relation to discontinuity.

directly to fire and is a more natural way of cooking; mostly associated with men and served to guests. ${ }^{[3]}$

Heidegger and Foucault state the importance of the notion of discontinuity by the division of the infinite into finites by the act of measurement. ${ }^{[4]}$ The act of measurement made it possible for man to make sense of his environment which brings us to a new distinction: the notion of opposition. Opposition is to state the difference that occurs between at least two discontinuities. Oppositions make it possible to define (measure) the differences between things. However, when defining those differences one also defines the similarities as G. Deleuze states: 'Only that which is alike differs and only differences are alike'. ${ }^{[5]}$ Two oppositional discontinuities are thus related as M. Foucault says 'there is no similitude and no distinction, ...that is not the result of a precise operation and of the application of a preliminary criterion. ${ }^{[6]}$ So oppositions indicate both the differences and the similarities between discontinuities that are arbitrary to a certain degree which can be exemplified by the diagram of contrast hues of grey in Figure 3.

Since Saussure, the formal discourse of structuralism has deduced the problem of signification into oppositions. Morphemes, phonemes, etc. the discontinuous components of spoken language can be utilized in a communicational construct only because they differ from each other. ${ }^{[7]} A$ meaningful communicational structure can be set with two terms that oppose each other with respect to their physical presence. Be it in the form of language we speak or in a form of different semiological structure, the formation of the sign requires two oppositional components; one with a physical amplitude that is perceived by sensory organs, and the other that lacks physical presence which is conceived by the cognition. Those components cannot constitute a meaningful structure unless they differ from each other and an opposition between them is formed. For example, a meaningful lingual structure cannot be formed only with the sound ' $A$ '.

Aesthetics, Rationality, Typology, Building Program, Meaning, Presence, etc. are various fictions Modern Architectural Episteme has constructed which in time started to have been conceived as natural facts. Among those fictions of Modern Architecture, the oppositional character of three fictions, that constitute less or more the fundamental basis of Modern Architectural Episteme will be discussed within the scope of this text:

\section{Opposition Between the Unit and the Whole}

Aesthetics can be regarded as a fiction of Modern Architectural Episteme, which is constructed by the opposition between the compositional unit and whole.

\begin{tabular}{|l|l|l|}
\hline Opposition & Fictions of Modern Architecture & Critical Review \\
\hline Unit and Whole & Aesthetics & Field Condition \\
\hline Building and Topography & Presence & Absence \\
\hline Motivated and Unmotivated Sign & Self Referential Sign & Indexical Architecture \\
\hline
\end{tabular}

Figure 4. The oppositional fictions of modern architectural episteme and their critical review. 


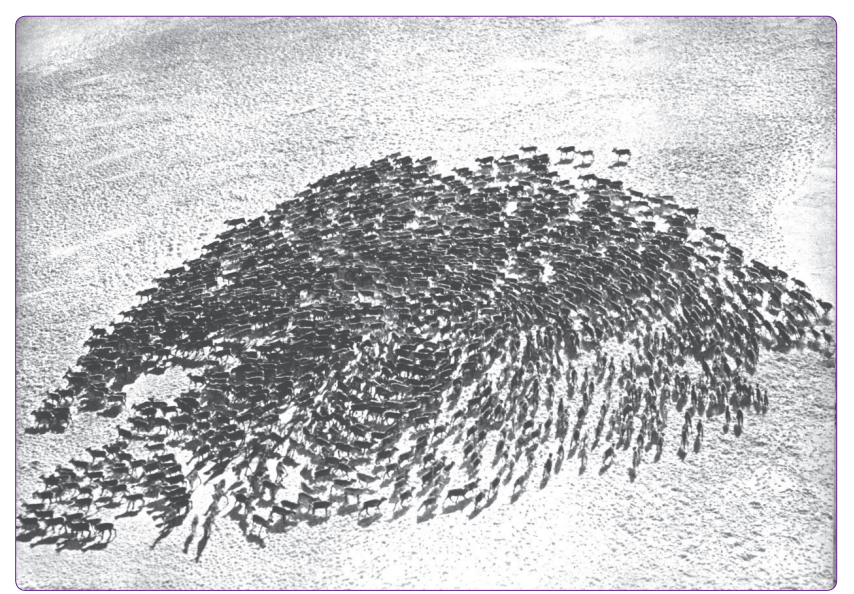

Figure 5. The Field Condition as stated by Allen., S., : Rein Deer Herd Reacting to a Helicopter Flying Overhead. ${ }^{[8]}$

One definition of the aesthetics in Modern Architecture is the attempt to reach to a compositional whole such that no unit can be added or subtracted. That is why the machine is considered to be a cultural product Modern Architecture aestheticized in that when a piece of it is taken away the machine will break down.

However, there are formal patterns that cannot be determined by the unit to whole relationship. Such patterns having mostly a chaotic character are the formal or spatial matrices of differing components and are called by S. Allen as the Field Conditions. The behavioral pattern of the flocks, herds, packs, swarms, and crowds, can set an example for such a phenomenon. Although it is difficult to determine a formula for a field condition it can be simulated computationally with only a few number of algorithmic lines. For instance, the following three line algorithm for each boid will adequately simulate the behavioral pattern of a herd of reindeers reacting to a helicopter flying overhead (Figure 5):

"(1) maintain a minimum distance from other objects in the environment (obstacles as well as other boids); (2) match velocities with other boids in the neighborhood; (3) move toward the perceived center of mass of boids in its neighborhood". ${ }^{[8]}$
Cordoba Mosque is usually given as an architectural example for the field condition. Like many multicolumn mosques, the vertical supportive elements in Cordoba mosque too, spread into the space uniformly. Unlike the reindeer herd example the columns in Cordoba Mosque as the components that sustain the field condition are not mobile but static. However, the subject in the space is mobile and the smallest bit of his movement inside Cordoba mosque will cause dramatic changes in his spatial perception. This is exactly what is meant by the term field condition. Peter Eisenman's Memorial to the Murdered Jews of Europe can said to have a similar spatial perceptual effect, which cannot be explained by the Modern Architectural aesthetic theories (Figure 6).

\section{Opposition Between the Building and the Topography}

The object of Modern Architecture can said to be designed for the subject seeing through the eye of the mind. That is the reason why it is regarded so important for the building to be perceived separately from its surrounding environment namely, the urban and natural topography. To see through the eye of the mind is a manifestation of the rational vision of the subject. Ratio by definition is the act of proportional measurement of forms and sizes that the subject sees. Ratio and thinking mind, since Descartes have been regarded as the fundamental proof of existence: "Cogito ergo sum: I think therefore I exist" The building standing upright on the ground has been regarded as the sign of resistance to one of the fundamental forces of he nature: The gravity. The opposition between the building and the topography has therefore been the persistence of the architectural presence and the formal expression of the thinking mind even before the Modern Architecture. Nonetheless it is a mind set Modern Architecture most willingly inherited and sustained. ${ }^{[9]}$

However, the opposition between the building and the topography is not the only way for the architectural idea to manifest itself. One of the earliest examples

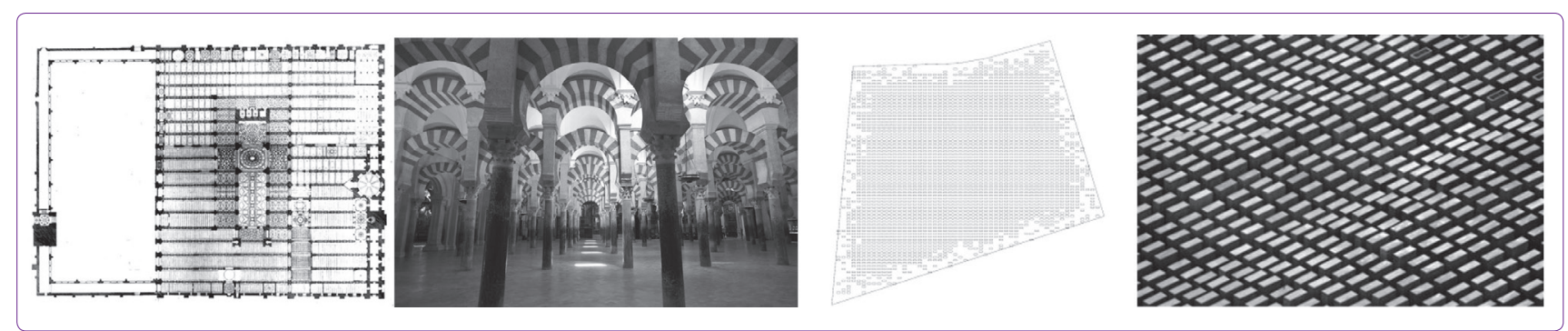

Figure 6. Field Condition: Cordoba Mosque and Memorial to the Murdered Jews of Europe. ${ }^{[20-23]}$ 
of architectural designs that the building is not perceived as an oppositional entity on the topography is the Vietnam Memorial in Washington.

Peter Eisenman's Cultural Center in Santiago De Compostela in Spain, and J. De Smedt's Youth Center in Copanhagen (Figure 7) in Denmark are examples of such a formal language which emanates from the absence of a distinction between the building and the ground such that building and topography have become the components of the same spatial continuum where the architectural usages acquire existence in between the negative spaces of built topography.

Considering the given examples one might ask where the beneath and top, rear and front, left and right of those buildings are. Moreover, where the outside begins and where the inside ends.

\section{Opposition Between the Motivated and the Unmotivated Sign}

Examining the signs of architecture can show the role of oppositions that they play in the construction of them. Iconic signs indicate a way of signification in which the relation between the signifier and the signified depends on a resemblance. Photographs are the iconic signs of the physical reality that they depict. Symbolic signs, on the other hand, denote an arbitrary relation between the signifier and the signified. The spoken language is based on symbolic signs to a greater extend. There is not a reasonable answer to why we call a photograph, 'a photograph'. Majority of the signs of architecture are iconic signs, which turn into symbolic signs as they are used and the usages turn into habits in time. ${ }^{[10]}$ This has both positive and negative aspects. The symbolical value of the architectural episteme denotes a pragmatic situation in terms of its impartibility for we can learn it through symbolic conventions and convey it to the future generations. The negative aspect of it is that the stagnation of symbolic signs causes the formation of the cliché in the architectural language. Type forms and building types can be given as the instances of such formations.

Maison Dom-Ino of Le Corbusier is considered to be a self-referential sign, which looks nothing, but like its purpose of use. Corbusier argues that every single architectural design would bear resemblance to this self-referential sign, being in an iconic relationship with it. ${ }^{[1]}$ Iconic signs dominate Modern Architecture as seen in brutalist designs like Eduardo Souto de Moura's Braga Municaipal Stadium (2011), where the section and elevation of the building can said to be in an iconic relationship. Also, a one to one (equal) relation in Richard Meier's Smith House (1967), a one to

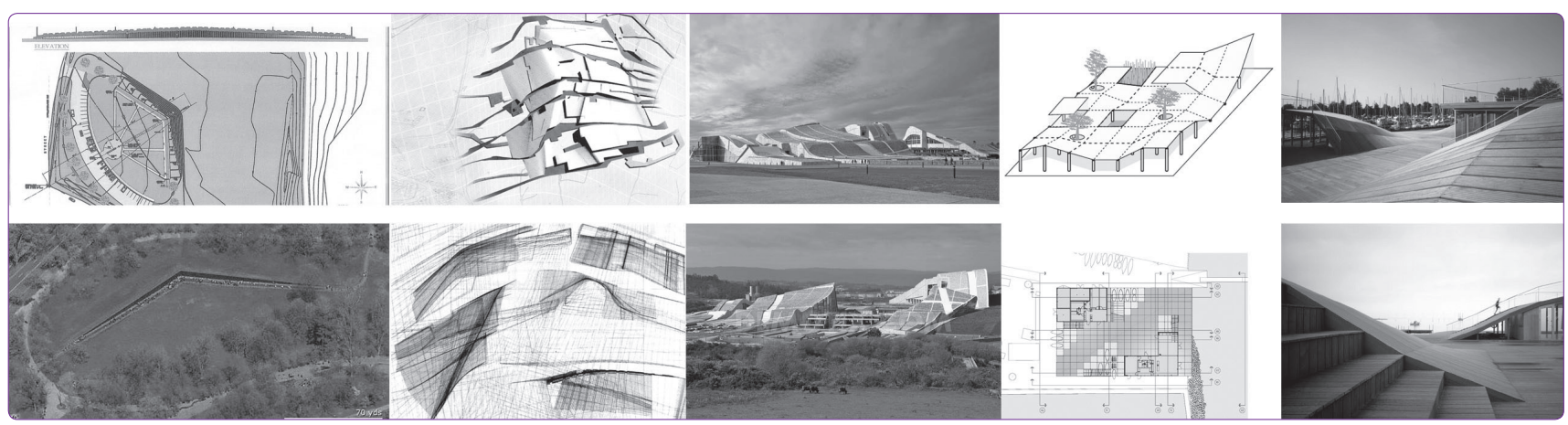

Figure 7. Absence: Vietnam Memorial in Washington, Peter Eisenman's Cultural Center in Santiago De Compostela in Spain, and J. De Smedt's Youth Center in Copanhagen in Denmark. ${ }^{[24-30]}$

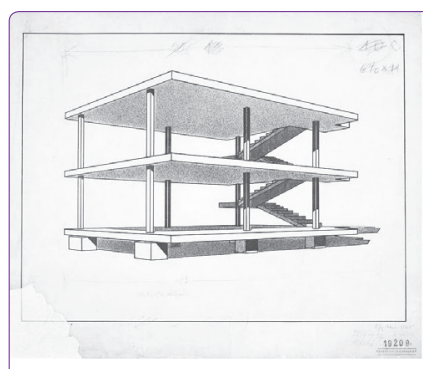

maison dom-ino
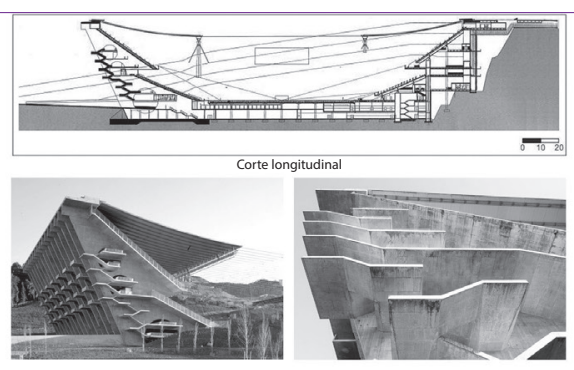

braga stadium
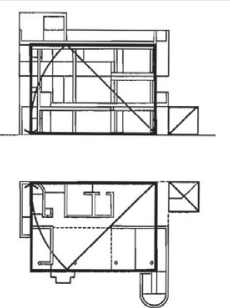

equal

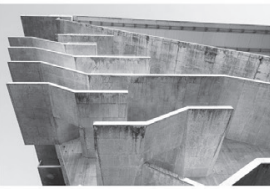

Figure 8. The Self-Referential Sign: Maison Dom-Ino; Section to Elevation Relationship as Iconic Sign Value: Braga Stadium; Plan to
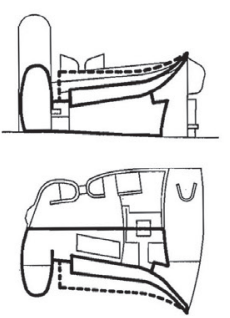

one to one half plan to section relation
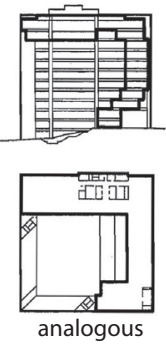
Section Relation as Iconic Sign Value: Smith House, Ronchamp Chapel, and Ford Foundation. ${ }^{[31-34]}$ 


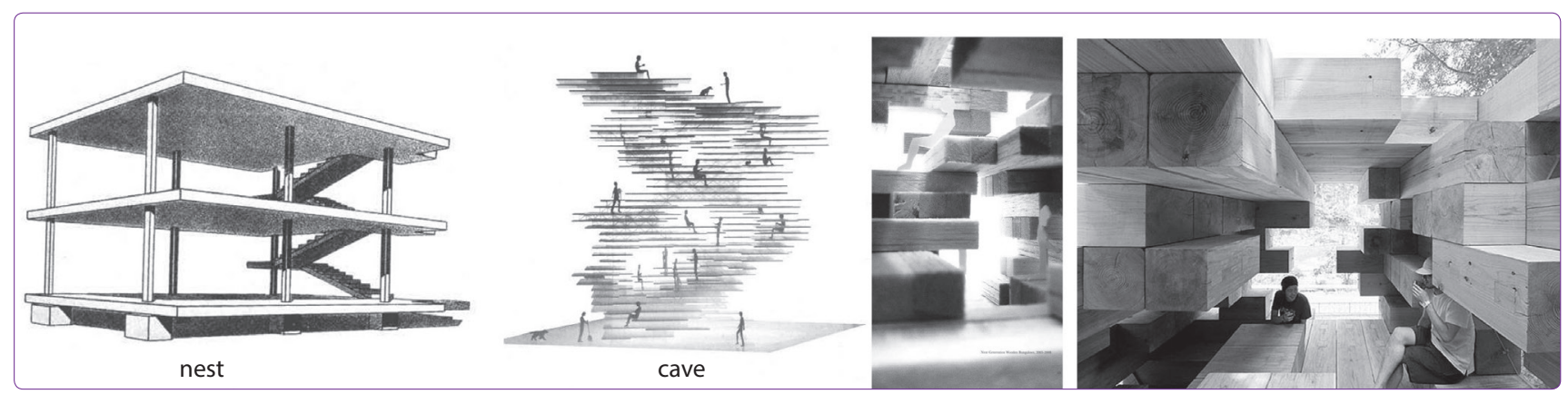

Figure 9. Nest vs. Cave by Sou Fujimoto. ${ }^{[16,35]}$

one half relation in Le Corbusier's Ronchamp Chapel (1955) and an analogous relation in Kevin Roche's Ford Foundation $(1955)^{[12]}$ can be observed between the plan and the section representation of the buildings which concludes us to think that the plan and section are constituted in an iconic sign relationship with each other (Figure 8).

Furthermore, the structural buildings like the roof structure of Stuttgart Airport Terminal Building (1998) by Meinhard von Gerkan, can said to be in an iconic sign relation with the distribution schemata of the static load that they have to bear. In fact, modern architectural sign in terms of spatial organization is structured such that the principle of the conservation of energy that supposes 'bodies in motion follow the shortest path possible' is satisfied. That is why for modern architectural discourse, the form of the architectural space is regarded as the signifier of its purpose of use (summarized with the statement 'form follows function'). ${ }^{[13]}$

So rare as they might be among the sign system of architecture, the Indexical Signs are of great value for the definition of architectural creativeness. An indexical sign by definition denotes an existential relationship between the signifier and the signified. The foot- print on the surface of the moon is the indexical sign of the man who is now absent but has once been present there. ${ }^{[14]}$ Sou Fujimoto explains the indexical sign condition in architecture with two opposing images of the nest and the cave (Figure 9). Whilst the nest has been produced for a certain purpose of use, the cave is a found space in which the appropriate forms for functions await to be discovered by its user. To him:

'As an functionalist archetype, a nest is prepared according to inhabitants' sense of confortability while a cave exists regardless of convenience or otherwise to its inhabitants; it remains indifferent. Upon entering a cave humanity adeptly assimilate to landscape by interpreting the various hints of convexo-concave surfaces and scales" ${ }^{\text {[15] }}$

In Sou Fujimoto's Cave Design (2008), where the stacks of elongated square sectioned slabs of wood come together to form the architectural space, the user decides how the fragments of the spatial form will be associated with the way in which he uses them, according to his own static and dynamic measurements. In his Cave the determination of where to rest, study and eat happens in the existential relationship the user develops with the space (Figure 9).
Building Designs (Group 1)

Berlin Memorial to the Murdered Jews of Europe, Peter Eisenman,

Galicia City of Culture, Santiago de Compostela, Peter Eisenman, 2013

2004 Cave, Sou Fujimoto, 2008

Building Designs (Group 2)

2011 Porto School of Architecture, Alvaro Siza, 1995

Smith House, Richard Meier, 1967

Braga Municipal Stadium, Eduardo Souto de Moura,
Opposition

unit $x$ whole

building $x$ topography

iconic $\mathrm{x}$ indexical

Opposition

unit $x$ whole

building $x$ topography

iconic $\mathrm{x}$ indexical

Figure 10. The visual image list of buildings used in the questionnaire. 
The indexical sign in architecture is constructed with what is called by the theoreticians the unmotivated sign. The motivation of a sign increases with the possibility of its being accepted as a sign by its users. In spoken English, the word 'nineteen' is said to be more motivated with being a sign than the word 'twenty'. For architecture the indexical sign is like opening a box for the first time that refers to exploring new form and function relationships while the iconic sign refers to relationships that are becoming ever more cliché.

\section{A Survey on the Legibility of Architectonic Discontinuities and Oppositions}

A questionnaire form was created for ten B. Arch. and $M$. Arch. students to test the ideas within the content of this text, which mainly involve the conceivability of the oppositions that are discussed to be the basic structural elements of the Modern Architectural Episteme. The questionnaire includes six visual images of the buildings stated in the table below:

Among those visual building images, Group 1 buildings of Cave Design of Sou Fujimoto, Cultural Center in Santiago and Memorial to the Murdered Jews of Europe in Berlin by Peter Eisenman were the probes to see whether the students could identify that those images represented a less oppositional character than the rest of the building images with more oppositional character. $^{[17]}$

The data derived from the questionnaire showed that the opposition between the unit and the whole that is considered as the basis of the architectural aesthetics in Modern Architectural episteme could not be identified properly. Half of the students opted for the existence of an oppositional relationship between the unit and the whole while the other half did not. The indifference in distinction of the opposition between the unit and whole may be related to the students' insight to what an architectural composition have to be (it is a whole from which no unit can subtracted or added.) What the students see in the visual images of the given designs were a compositional whole, therefore they did not identify any opposition among its compositional units (Figure 11).

Collected data show that the opposition between the building and the topography and the oppositional relationship between the iconic and indexical signs of architecture could be identified almost twice as better than the opposition between the unit and whole. Furthermore, the visual images of the Group 2 buildings of Smith House by Richard Meier, Braga Municipal Stadium by Eduardo Souto de Moura, and Porto School

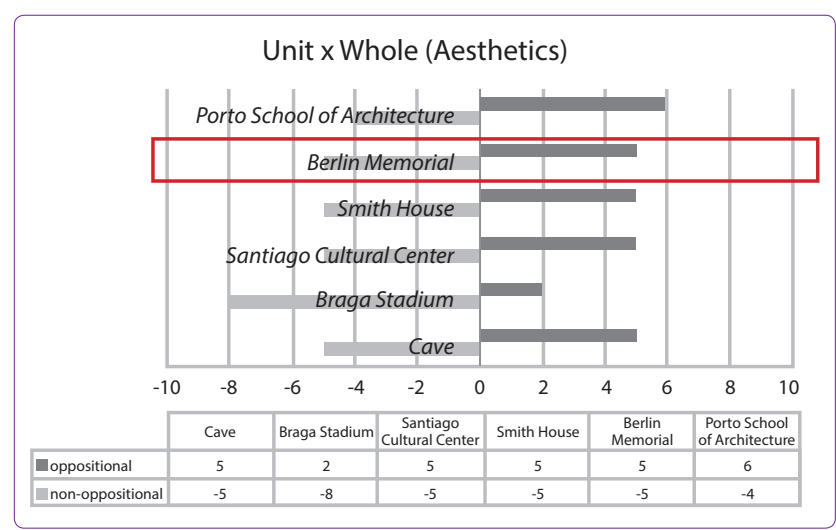

Figure 11. The oppositional values of the aesthetic fiction of the modern architectural episteme.

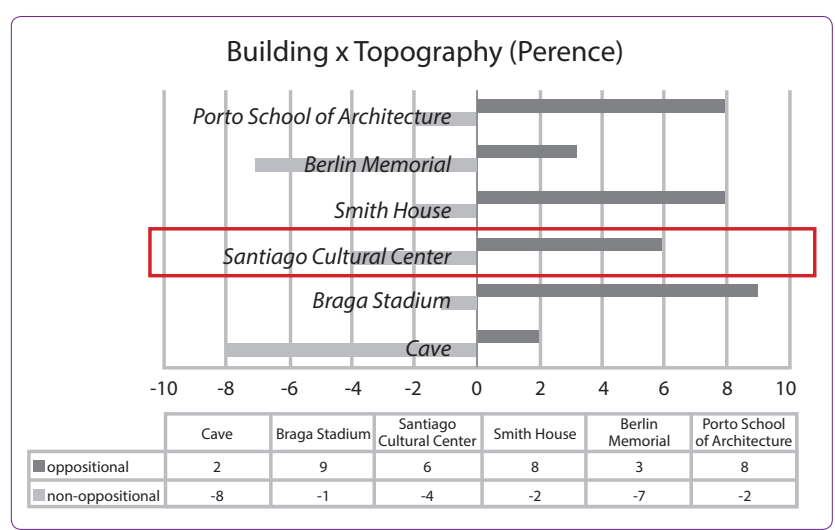

Figure 12. The oppositional values of the fiction of presence of the modern architectural episteme.



Figure 13. The oppositional values of the fiction of sign value of the modern architectural episteme.

of Architecture by Alvaro Siza that were selected to represent the stated oppositions of Modern Architectural Episteme were identified with an accuracy of more than $70 \%$. However, Santiago Cultural Center by Eisenman, which was the probe to detect the expected oppositional difference, did not yield a meaningful oppositional value. 6 out of 10 students stated they con- 
ceive an oppositional relationship between the building form and the topography while 4 of them replied that they did not. Yet, the oppositional value for this building is $30 \%$ less than the average value stated for the Group 2 buildings (Figure 12).

The legibility of the architectural sign value of the buildings was quite conceivable as the collected data show the probe buildings in Group 1 were responded to be significantly less oppositional than the buildings in Group 2. This has been interpreted as an indication that the surveyed architectural students have absorbed the form and function relationship, which lies in the focus of architectural education. The responses showed the legibility of the opposition between building and topography and the opposition between the iconic and the indexical sign value of the architectural object were highly correlational with a value of 0.87 (Figure 13).

One last issue that has been surveyed in the questionnaire form was the impartibility and permeability of the architectural knowledge. The responses to the questions 'How many pages would it take for you to describe the given building in a written text?' and 'If these were your designs which academic term would you prefer to take it?' were highly correlational (with a value of 0.83 ) which showed that as the design problem becomes more complex, students prefer to deal with it in the later academic years. The difficulty and learning sequence according to the majority of the students is as goes: (1) Cave, (2) Berlin Memorial, (3) Porto School of Architecture, (4) Smith House, (5) Braga Stadium, (6) Santiago Cultural Center. This has been interpreted as one of the defining properties of knowledge structures that depend on conceptual oppositions because they divide the episteme into discontinuities, or strata as Deleuze and Guattari call it [18], and define a hierarchy that depend on the level of difficulty in between. As in the spoken language, those oppositional discontinuities are structured in a linear temporal chain within the learning process.

\section{Conclusions}

Discontinuities and oppositions are of significant concern in architectural knowledge as much as in any other epistemological domain. However, new sociological relationships define ever more complex problems and technological advancements become more capable of probing into these problems that oppositional epistemological structures fall short in defining them. Architectural knowledge in educational institutions is usually thought in a linear sequence.
This linearity depends on subject's level of complexity or its temporal presence. Meaning that the order of information follows the same temporal sequence with the amount of its content or the historical array of its happening. It is a onedimensional straight path with a definite beginning, an origin as Eisenman calls it, ${ }^{[19]}$ with directionality towards the future. This epistemological path never bends, never makes turns or turn backs. If it does, it is for a good purpose, namely for the purpose of the mnemonic sturdiness of the matter in question, turning it into an architectonic symbol so that it completely becomes arbitrary to its users.

But there can be another way for us to conceive the structure of the Architectural Episteme. A matrix or a field that has an augmented dimensionality and a wider range of combinational probabilities can help us visualize it. Since its dimensionality -two instead of one, it does not necessarily have to have an origin. Depending less on the oppositions it could allow feedbacks and have a relational character. One could fill in the determinants of this matrix in any combination possible and construct a synaptic pattern.

\section{References}

Barthes, R. (1977) Elements of Semiology, New York, C. Hill and Wang, pp. 58-71.

Leach, E. (1964) 'Anthropological Aspects of Language: Animal Categories and Verbal Abuse', Ed. E. Lennenberg, New Directions in the Study of Language, Cambridge, MIT Press, pp. 23-63.

Lévi-Strauss, C. (2008) 'The Culinary Triangle', Ed. C. Counihan and P. Van Esterikp, Food and Culture, New York, Routledge, pp. 36-43.

Heidegger, M. (2001) 'Building, Dwelling, Thinking', Ed. N. Leach, Rethinking Architecture: A Reader in Cultural Theory, New York, Routledge, pp. 100-109.

Deleuze, G. (2004) Difference and Repetition, New York, Continuum, pp. 142,143.

Foucault, M. (2002) The Order of Things: An Archeology of the Human Sciences, New York, Routledge, pp. xvi-xxvi.

Saussure, F. (2000) Course in General Linguistics, Chicago, Open Court, pp. 8-17.

Allen, S. (1999) Points + Lines: Diagrams and Projects for the City, New York, Princeton Architectural Press, pp. 93-99.

Eisenman, P. (1992) 'Visions' Unfolding: Architecture in the Age of Electronic Media", Domus, 734:17-24.

Eco, U. (1980) 'Function and Sign: The Semiotics of Architecture', Sign, Symbols and Architecture, Ed. G. Broadbent, et. al., New York, John Wiley \& Sons, pp. 10-69.

Eisenman, P. (1998) 'Aspects of Modernism: Maison Domino and the Self Referential Sign', Ed. K. M. Hays, Oppositions: Reader, Princeton Architectural Press, pp. 189-198.

Roger, H.C., Pause, M. (2012) Precedents in Architecture: Analytic Diagrams, Formative Ideas, and Partis, New Jersey, John Wiley and Sons Inc., pp. 232-234. 
Eco, U., Ibid., pp. 10-69.

Eisenman, P. (1999) Diagram Diaries, New York, Universe Publishing, pp. 195.

Fujimoto, S. (2008) Primitive Future, INAX, Tokyo, pp. 22-25.

Fujimoto, S., Ibid, pp. 22,23,120.

The questionnaire form can be viewed in: https://docs. google.com/forms/d/1UeFPynplDJbe0QetXPpODzyFbn9 34Ub7CiVUJ2s0YI/viewform.

Deleuze, G., Guattari, F. (1988) A Thousand Plateaus: Capitalism and Schizophrenia, Minneapolis, University of Minnesota Press, pp. 158-159.

Eisenman, P. (1984) 'The end of the classical: the end of the beginning, the end of the end', Perspecta, 21:154-173.

\section{Internet References}

Cordoba Mosque

http://www.deconcrete.org/wp-content/uploads/2012/01/ Dismantling-sitesof-power_Cordoba-Mosque-and-Cathedral.jpg (09.03.2015)

http://2ca54c85d3f608494402-1c6b4b69d2498d95ab6e291a3fb28b64.r36.cf1.rackcdn.com/41/1/large. jpg(09.03.2015)

Memorial to the Murdered Jews of Europe

https://generativelandscapes.files.wordpress. com/2014/10/step04_c.png?w=290 (09.03.2015)

http://controversies.msa.ac.uk/blogs/memorialberlin/fil es/2012/04/6a00d8341c60bf53ef00e54f4d1cd98834800wi.jpg (09.03.2015) Washington Vietnam Memorial

http://www.msvietnammemorial.com/Tupelo/Home_files/ shapeimage_2.png (09.03.2015)

http://gardenrant.com/wp-content/uploads/2013/08/vietnam-memorial1.jpg (09.03.2015)

City of Culture Galicia Santiago de Compostella

h t t p : / / p a y I o a d.cargocollective. com/1/1/61240/1668531/1b.2.jpg (09.03.2015)

https://ksacommunity.osu.edu/system/files/abstract_machine_city_of_culture_of_galicia.jpg (09.03.2015)

http://archrecord.construction.com/projects/portfolio/2011/06/images/Galicia-Archive-1_Exterior.jpg (09.03.2015)

http://static4.demotix.com/sites/default/ files/imagecache/a_scale_large/1900-8/ photos/1365513276-another-spanish-project-unfinished-city-of-culture-ofgalicia_1940138.jpg (09.03.2015) Maritime Youth Center, Denmark

http://jdsa.eu/mar/ (09.03.2015) Maison Dom-Ino, Le Corbusier

http://www.fondationlecorbusier.fr/corbuweb/morpheus. aspx? sysld=13\&IrisObjectld $=5972 \&$ sysLanguage $=\mathrm{fr}-$ fr\&itemPos=3\&itemSort=frfr_sort_string1\&itemCount $=$ 4\&sysParentName $=$ Home\&sysParentld $=11$ (10.03.2014) Braga Municipal Stadium

https://s3.amazonaws.com/qcon-assetsproduction/images/provas/24125/Imagem\%20020.jpg (10.03.2014)

http://block.arch.ethz.ch/equilibrium/images/drawings/ sideview_part_2_bw_1399983245.jpg

h t t p: / / payload 320 . cargocollective. com/1/0/20961/8709949/dacian-grozabraga-municipalstadium-08-1207_2000.jpg (10.03.2014)

Cave, Sou Fujimoto

http://www.woodindesign.com/wp-content/uploads/2012/05/Sou-Fujimoto-Final-Wooden-House.jpg (10.03.2014)

Key words: Architectural narrative; discontinuity; field condition; index architecture; modern architectural episteme; opposition.

Anahtar sözcükler: Mimari anlat; süreksizlik; alan durumu; indeks mimari; modern mimarlık bilgisi; karşıtık. 